\title{
Wind Motions around the Tropical Cirrus Using Simultaneous Radar and Lidar Observations over Gadanki $\left(13.45^{\circ} \mathrm{N}, 79.18^{\circ} \mathrm{E}\right)$, India
}

\author{
C. Dhananjaya Rao1,2, M. Arunachalam Srinivasan ${ }^{1 *}$, M. Krishnaiah'1, \\ Y. Bhavani Kumar', S. V. B. Rao ${ }^{1}$ \\ ${ }^{1}$ Department of Physics, Sri Venkateswara University, Tirupati, India \\ ${ }^{2}$ Seshachala Institute of Technology, Puttur, India \\ ${ }^{3}$ National Atmospheric Research Laboratory (NARL), Gadanki, India \\ Email: ${ }^{*}$ arun82chalam2001@yahoo.co.in
}

Received 2 August 2014; revised 28 August 2014; accepted 16 September 2014

Copyright (C) 2014 by authors and Scientific Research Publishing Inc.

This work is licensed under the Creative Commons Attribution International License (CC BY). http://creativecommons.org/licenses/by/4.0/

\section{c) (i) Open Access}

\section{Abstract}

The present study describes variation of peak linear depolarization ratio (LDR) with wind around the cloud altitude using simultaneous observation of winds and cirrus cloud for the first time using Indian MST radar and polarization lidar co-located over a low latitude station Gadanki $\left(13.7^{\circ} \mathrm{N}\right.$ and $79.2^{\circ} \mathrm{E}$ ). Three different cases of passage of the cirrus at different altitudes are noticed, one during a North-East monsoon day and other two during South-West monsoon days. The zonal wind below the cloud height has shown similar variation with LDR during 02 November 2006 and the meridional wind within the cloud height during 25 July 2007 and 08 June 2006 has shown opposite variation with LDR. Even though there is a significant increase in zonal wind due to the existence of tropical easterly jet (TEJ) above cloud height during 25 July 2007 and 08 June 2006, also, the vertical wind is found to be continuously varying during 25 July 2007 and it is upward dominant in the initial stage and is mostly downward in the later stage of observation on $08 \mathrm{June} 2006$, there is a slight descent in cloud altitude only during 25 July 2007. Thus, the wind above the cloud height alone may not affect the ascent/descent of the cloud top altitude. The potential temperature gradient is high within the cloud heights when the cirrus present near the cold point tropopause indicates the maximum air-mass mixing near the tropopause.

\section{Keywords}

Cirrus Cloud, LDR, Winds, TEJ, Lidar, Radar

\footnotetext{
*Corresponding author.
}

How to cite this paper: Rao, C.D., Srinivasan, M.A., Krishnaiah, M., Kumar, Y.B. and Rao, S.V.B. (2014) Wind Motions around the Tropical Cirrus Using Simultaneous Radar and Lidar Observations over Gadanki $\left(13.45^{\circ} \mathrm{N}, 79.18^{\circ} \mathrm{E}\right)$, India. International Journal of Geosciences, 5, 1241-1253. http://dx.doi.org/10.4236/ijg.2014.511103 


\section{Introduction}

Cirrus clouds have long fascinated the scientists because of their variable microphysical and optical properties. They are thin wispy clouds blown in high winds and intermittently associated with strong turbulence in the region of upper troposphere and lower stratosphere [1]. These clouds will significantly affect the Earth's climate through infrared absorption and solar albedo effect [2]. Their contribution to the radiation budget strongly depends on their optical and geometrical properties. Space borne lidars, in situ measurements and ground based experiments showed that nearly, 20\% - 30\% of Earth's atmosphere is covered with cirrus clouds. They are globally distributed and composed predominantly of ice particles (e.g. [3]). Their frequency of occurrence is so high over tropics causing a significant warming to the equilibrium climate through the interaction processes between cloud and radiation [4].

Cirrus clouds form at different altitudes in different geographical locations, ranging from 8 to $20 \mathrm{~km}$ [5]. For example, at mid-latitudes, thin cirrus will occur between 8.5 and $11.5 \mathrm{~km}$ altitude region [6]-[10] with a persistence of few hours only which is because of rapid crystal growth and dissipation by precipitation due to high tropopause temperatures [11] and over tropics they usually occur in the altitude region of $8-17 \mathrm{~km}$ [12]. In tropics the maximum occurrence of cirrus clouds is in the $13-14 \mathrm{~km}$ altitude region [12]. The mean altitude of cirrus cloud will increase with the decrease in cold point temperature near the tropopause [1] [12]. They have also reported that sharp discontinuity in vertical gradient of eddy diffusion coefficient due to divergence followed by convergence above in the strong and persistent region of cirrus is responsible for the formation of cirrus. In fact, these clouds are confined to occur very near to the tropopause region [13]-[16]. [17] has also reported that the horizontal extent of cirrus can be more than $\sim 1000 \mathrm{~km}$ and they can persist for few hours to few days in the tropical region [12]. The reason for the long time persistence of cirrus clouds near the tropical region is due to the utilization of absorbed infrared radiation for lifting the cloud layer under weak vertical wind instead of raising the temperature of local air parcel with the absorbed radiation [11]. Especially, in tropics these clouds will often appear below the tropopause and those clouds that appear near tropopause will act as tropopause tracers [18].

Cirrus clouds are composed of complex structures and are spatially inhomogeneous due to shear in the horizontal wind, therefore alter the radiative properties [19]. In general, atmospheric circulation will be affected by vertical gradient of radiative forcing due to cirrus clouds especially in the UTLS region (e.g. [20]). Since, cirrus clouds will influence the dehydrated air entering into the UTLS region there by affecting the climate change. Cirrus clouds will also play an important role on the atmospheric chemistry by reducing the ozone concentration and may also take active part in the chlorine chemistry during their presence especially near tropical and midlatitude regions [21].

The accurate determination of the microphysical properties and vertical structure of cirrus clouds necessitates knowledge on dynamical processes (e.g. [22]). In this context, very few studies have focused on the wind motions around cirrus clouds [10] [23] [24]. Cirrus clouds can be monitored with the help of either ground based/ space-borne lidars or a combination of both [6]. At the same time the wind information around the cirrus clouds can be monitored with the help of clear-air radars. The present study describes the variation of winds during the passage of cirrus clouds noticed at different altitudes using three different Cases over Gadanki.

\section{Data and Methodology}

\subsection{MST Radar}

The present observations were made using VHF radar located at Gadanki $\left(13.47^{\circ} \mathrm{N}, 79.18^{\circ} \mathrm{E}\right)$, a tropical station in India. The radar system details are given by [25]. The data collected by the VHF radar operated in Doppler Beam Swinging mode with six beams (viz. East, West, Zenith-X, Zenith-Y, North and South) during which the passage of cirrus clouds over Gadanki by the co-located lidar for the three Cases, i.e., on 02 November 2006, 25 July 2007 and on 08 June 2006 with a height resolution of $150 \mathrm{~m}$ and a temporal resolution of 4 min has been used to study the continuous wind motions around the tropical cirrus clouds.

\subsection{Mie Lidar}

A monostatic, dual polarization lidar (operated at $532 \mathrm{~nm}$ ) installed at National Atmospheric Research Laboratory (NARL), Gadanki $\left(13.45^{\circ} \mathrm{N}, 79.18^{\circ} \mathrm{E}\right)$ has been used for observing the spatial and temporal variations of 
cirrus clouds during 02 November 2006, 25 July 2007 and 08 June 2006. The detailed description of the lidar system can be found elsewhere [26]. The altitude profiles of signal intensity received by linear and orthogonal polarization channels were obtained with a bin width of $2 \mu$ s (corresponding to an altitude resolution of $300 \mathrm{~m}$ ) and summed over 250 seconds constitutes the basic lidar signal. The lidar data were processed using algorithm described by [27] to estimate the altitude profile of particulate backscatter coefficient $\left(\beta_{\mathrm{a}}\right)$ from $7-30 \mathrm{~km}$ altitude range by taking the reference altitude as $30 \mathrm{~km}$ where the value of $\beta_{\mathrm{a}}$ is assumed to be insignificant. For lidar signal inversion, altitude profile of molecular backscatter coefficient $\left(\beta_{\mathrm{mol}}\right)$ is essential and is estimated using altitude profiles of pressure and temperature data from Radiosonde launched every day at 17:30 IST since August 2006 over Gadanki.

Further, we have used the particulate backscatter coefficient to determine the cloud vertical structure (cloud base and top altitudes), cloud backscatter coefficient $\left(\beta_{\mathrm{c}}\right)$ and the lidar derived Linear Depolarization Ratio (LDR). For the determination of cloud base and top altitudes, three basic methods were developed during Experimental cloud Lidar Pilot Study_ECLIPS [28]. They are: 1) the Differential Zero Crossing method [29], 2) the threshold method [28], and 3) a quantitative approach based on the clear air assumption [6]. In the present study, however, we used method-3, in order to determine the cloud base and cloud top altitudes.

\section{Method-3}

In this method, the altitude profiles of cloud backscatter coefficient $\beta_{\mathrm{c}}(\mathrm{z})$ has been calculated for the determination of cloud borders. First of all, we have computed the backscatter ratio $\mathrm{S}(\mathrm{z})$ of the lidar signal and then, the altitude profiles of the molecular backscatter coefficient $\beta_{\text {mol }}(\mathrm{z})$ has been obtained using the altitude profiles of the number density of molecules $\mathrm{N}_{\mathrm{mol}}(\mathrm{z})$ by averaging pressure and temperature profiles obtained by radiosonde. Now, the cloud backscatter coefficient $\beta_{\mathrm{c}}(\mathrm{z})$ can be computed by using the formula $\beta_{\mathrm{c}}(\mathrm{z})=(\mathrm{S}(\mathrm{z})-1) * \beta_{\text {mol }}(\mathrm{z})$ [10]. In order to determine the cloud borders, we have to find the threshold value of $\left.\beta_{\mathrm{c}}(\mathrm{z}), 1\right)$ which should be small enough to observe small variations in $\beta_{\mathrm{c}}(\mathrm{z})$ due to the presence of cloud particles, and 2) the threshold should be large enough to determine the uncertainties in the received signal at the cloud borders due to fluctuations in $\beta_{\mathrm{c}}(\mathrm{z})$. The threshold value can be changed arbitrarily to satisfy 1$)$ and 2). This low value of $\beta_{\mathrm{c}}(\mathrm{z})$ threshold will capture all the layers of enhanced scattering above the level of molecular and ambient aerosol backscatter, includes sub visual cirrus as defined by [6]. Now, the altitude profile of total backscatter $\beta_{\mathrm{t}}(\mathrm{z})=\left(\beta_{\mathrm{c}}(\mathrm{z})+\right.$ $\left.\beta_{\text {mol }}(\mathrm{z})\right)$ will be obtained by using the cloud backscatter coefficient $\beta_{\mathrm{t}}(\mathrm{z})$ using lidar. Finally, by plotting the $\beta_{\mathrm{t}}(\mathrm{z})$ and $\beta_{\text {mol }}(\mathrm{z})$ together, one can automatically retrieve the cloud base and top altitudes more accurately , since, there will be proper coincidence between profiles of $\beta_{\mathrm{t}}(\mathrm{z})$ and $\beta_{\text {mol }}(\mathrm{z})$ except in the cloud region. The reason for using method-3 in determining the cloud base and top altitudes is that, this method can give more precise values of cloud base and cloud top altitudes. Whereas, the methods- 1 and -2 which are closely related (distinguishes a change of slope from the decreasing total backscatter just below the cloud base to the sharp rise in backscatter above cloud base) requires fine tuning in order to avoid triggering of cloud base by random noise, short range spikes and also tuned to ignore small enhancements in backscatter below the cloud base caused by aerosol precondensation growth. In order to overcome some of the above mentioned problems, [6] have developed the method-3, which can be used for low-density clouds also. Hence we have used the method-3 for finding the vertical structure of the broad cirri form clouds.

In addition, we have used pressure to height converted 6 hourly zonal wind and temperature data sets available at 37 standard pressure levels $(1000 \mathrm{hPa}$ to $1 \mathrm{hPa})$ from ERA-Interim Reanalysis [30] downloaded from http://data-portal.ecmwf.int/ for the present study to depict effect of synoptic scale features on the passage of cirrus clouds over the observational site.

\section{Results and Discussion}

Wind variations around the cirrus clouds were monitored by using MST radar and Mie lidar co-located over Gadanki $\left(13.5^{\circ} \mathrm{N}, 79.18^{\circ} \mathrm{E}\right)$ (location map is shown in Figure 1) using three different cases, one during postmonsoon season and the other two during Indian summer monsoon.

Case-(a): Figure 2(a) shows the height-time section of cloud backscatter coefficient deduced from lidar showing the presence of cloud between the altitude regions of $13-14.8 \mathrm{~km}$ on 02 November 2006 between 01:15 - 01:55 LT. On this day the simultaneous wind information is available between 01:00 - 04:30 LT in Upper Troposphere and Lower Stratospheric region (Figure 4(a)). 


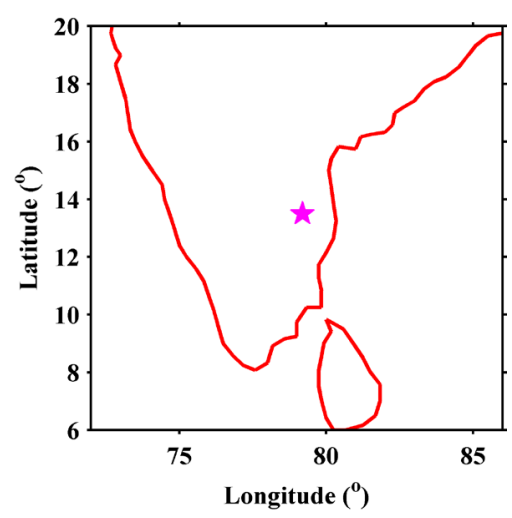

Figure 1. Location map of region of study ( $\star$ indicates Gadanki location).
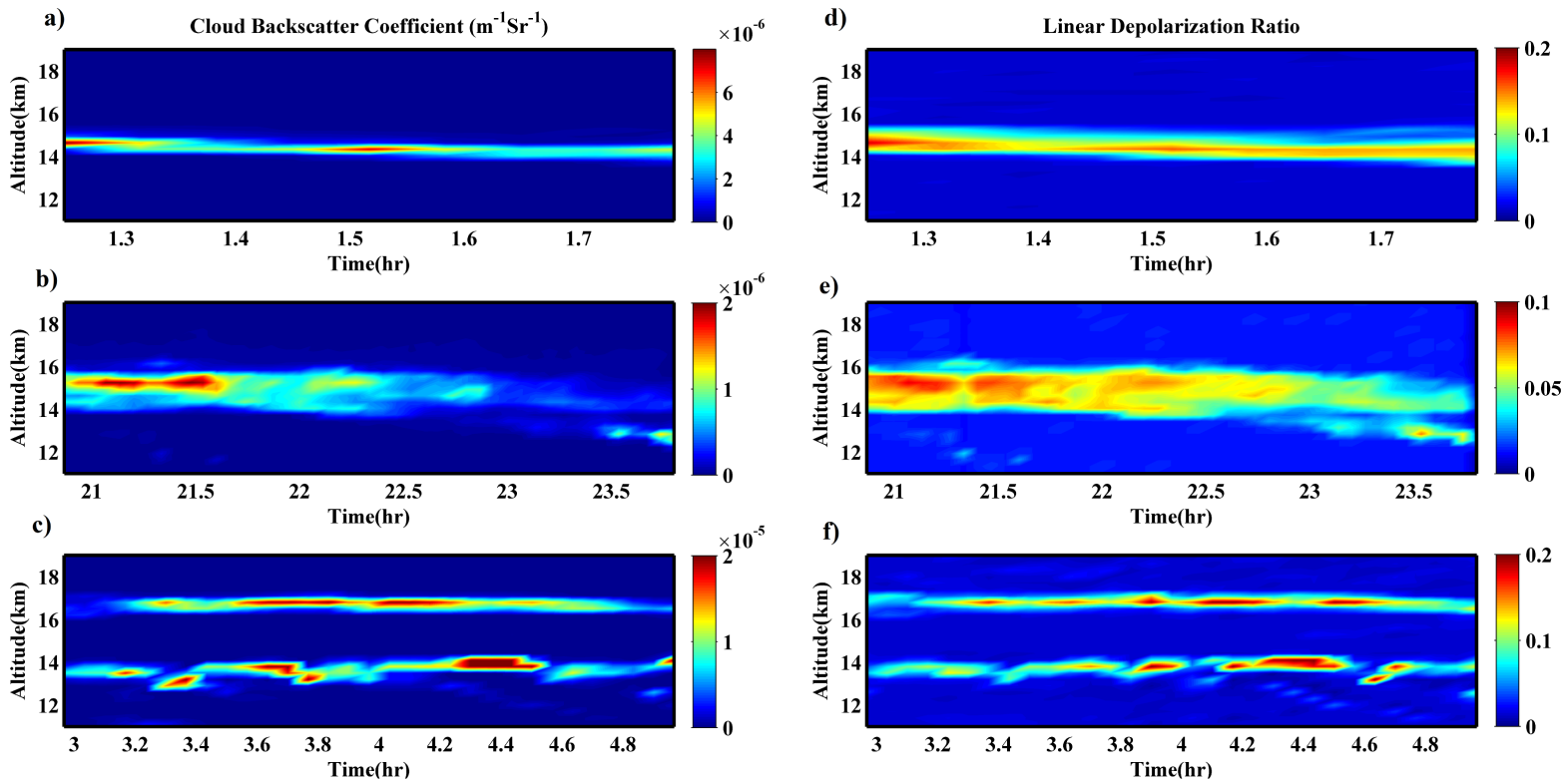

Figure 2. Time-altitude plots of (a)-(c) cloud backscatter coefficient $\left(\beta_{\mathrm{c}}(\mathrm{z}), \mathrm{m}^{-1} \cdot \mathrm{Sr}^{-1}\right)$ and (d)-(f) linear depolarization ratio (LDR) for 02 November 2006 between 01:15 - 01:55 LT (top panel), 25 July 2007 between 20:50 - 24:00 LT (middle panel) and 08 June 2006 between 03:00 - 05:00 LT (bottom panel), respectively.

Case-(b): On 25 July 2007 both lidar and MST radar observations were made simultaneously from 20:50 to 24:00 LT (Figure 2(b)). The presence of cirrus is noticed between $12.6-16.5 \mathrm{~km}$ and the corresponding wind information can be noticed from the winds determined using MST radar (Figure 4(b)).

Case-(c): The presence of multiple clouds is noticed at $\sim 12.4 \mathrm{~km}-14.5 \mathrm{~km}$ and $\sim 16.2-17.1 \mathrm{~km}$ altitude regions from $\beta_{c}$ between 03:00 - 05:00 LT on 08 June 2006 (Figure 2(c)) and its corresponding wind variation available between 02:00 - 05:30 LT can be noticed from the Figure 4(c).

Figures 2(a)-(c) describes the altitude-time plot of the cloud backscatter coefficient $\beta_{\mathrm{c}}$ calculated using lidar. During Case-(a) cirrus cloud is found to be present in the $\sim 13-14.8 \mathrm{~km}$ altitude region with cloud top altitude located at around $\sim 14.8 \mathrm{~km}$. During Case-(b), we have noticed the presence of cirrus at two different altitudes, one corresponding to cloud top of $\sim 16.5 \mathrm{~km}$ and another with a cloud top of $\sim 13.7 \mathrm{~km}$ which might be due to the detachment of cirrus from the original cloud which can be noticed from $\beta_{c}$ especially, between 23:00 to 24:00 LT (as in Figure 2(b)). In Case-(c), there is two layers of cirrus with cloud tops of $\sim 14.5 \mathrm{~km}$ and $\sim 17.2 \mathrm{~km}$ is found between 03:00 LT to 05:00 LT on 08 June 2006 respectively. Except in Cases- $(a)$ and - $(c)$, we have noticed a slight descent in the cloud top altitude in Case-(b) (as seen in Figure 2(b)) between 23:00 LT to 24:00 LT. 
In order to discriminate the cloud phase and also to observe the effect of wind on the cirrus cloud, we have calculated the values of Linear Depolarization Ratio (LDR) for all the three Cases. Figures 2(d)-(f) shows the height-time zenith lidar display of the LDR which is a trace of cirrus cloud. The peak LDR values are found to be $0.182,0.089$ and 0.23 for the Cases- $(a)$ to $-(c)$ respectively. [12] has classified that the cirrus clouds with LDR $<0.15$ are composed of liquid layer and those with LDR between $0.16-0.25$ are composed of super cooled layer (like ice). Hence, the cirrus clouds observed during Cases-( $a$ ) and - $(c)$ are composed of super cooled layer and in Case-(b) the cirrus cloud is composed of liquid layer. As reported by [31] cirrus cloud with low values of LDR corresponds to regular quasi-spherical or horizontally oriented and flat ice crystals. While, high values of LDR indicates randomly oriented and highly non-spherical ice particles. We have also noticed that the clouds occurring at higher altitudes (lower temperatures) during Case-(c) show high LDR than the clouds observed at lower altitudes (higher temperatures), during Cases- $(a)$ and $-(b)$ indicating strong dependence of LDR on the ambient temperature conditions of surroundings [32]. It is observed that low to moderate values of LDR indicating low ice water content, which is consistent with the earlier investigations [8] [12] [23] [33].

While classifying cirrus clouds as visible and sub visual, [6] has projected a threshold value for cloud optical depth (COD) as 0.03 for the sub visual cirrus cloud for the first time at an optical wavelength of $694 \mathrm{~nm}$. The values of COD are found to be 0.08 (visible) for the Case-(a), 0.04 (visible) for the Case- $(b)$ and 0.06 for the lower cloud layer (visible) and 0.001 for the upper cloud layer (sub-visual) for the Case-(c), respectively. It is clear from the values of COD for the present study that the COD shows a direct correlation with ambient temperature, since we have noticed cirrus at different altitudes during the cases of present study, which is in agreement with the previous results [12] [23] [24].

Further, we have determined the cloud base and top altitudes by using the method-3 as in [6] as shown in Figure 3. It is clear from this figure that, except in the cloud regions, the total backscatter coefficient $\beta_{\mathrm{t}}$ and the background molecular backscatter coefficient $\beta_{\text {mol }}$ were almost the same. Thus the regions, where the cloud backscatter coefficient $\beta_{\mathrm{c}}>1.21 \times 10^{-7} \mathrm{~km}^{-1} \cdot \mathrm{sr}^{-1}$ in Case- $(a), \beta_{\mathrm{c}}>6.17 \times 10^{-8} \mathrm{~km}^{-1} \cdot \mathrm{sr}^{-1}$ in Case- $(b)$ and $\beta_{\mathrm{c}}>$ $3.46 \times 10^{-7} \mathrm{~km}^{-1} \cdot \mathrm{sr}^{-1}$ in Case-(c) respectively were identified as clouds. Values of cloud base and top altitudes are found to be $\sim 13.0 \mathrm{~km}$ and $\sim 14.8 \mathrm{~km}$ for the Case-(a). From Figure 3(b) one can notice that there are two
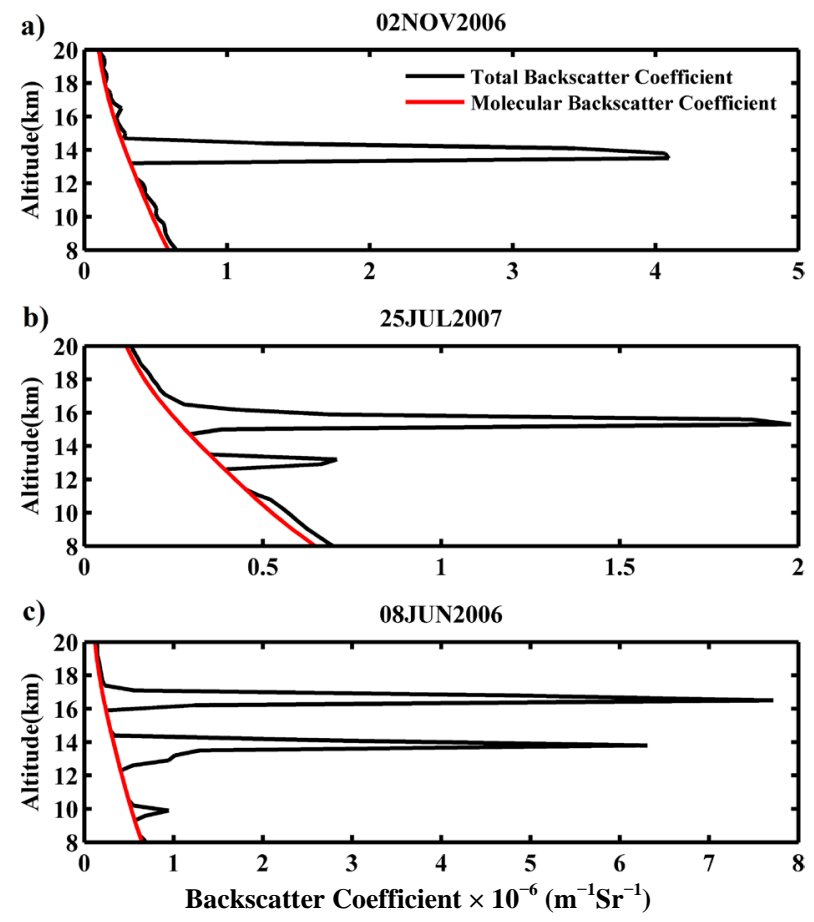

Figure 3. Altitude profile of $\beta_{\mathrm{c}}(\mathrm{z})+\beta_{\text {mol }}(\mathrm{z})$ observed by lidar (black line) and $\beta_{\text {mol }}(\mathrm{z})$ calculated from radiosondes (red line) for (a) 02 November 2006, (b) 25 July 2007 and (c) 08 June 2006. 
peaks one corresponding to regular cirrus which is noticed with cloud base and top altitudes at $\sim 14.6 \mathrm{~km}$ and $\sim 16.5 \mathrm{~km}$ and the other corresponding to the detached cloud with cloud base and top altitudes at $\sim 12.6 \mathrm{~km}$ and $\sim 13.7 \mathrm{~km}$ noticed between 23:00 - 24:00 LT for the Case-(b). During Case-(c) there are two cirrus layers one with cloud base and top altitudes at $\sim 12.3 \mathrm{~km}$ and $\sim 14.5 \mathrm{~km}$ and the other at $\sim 16.1 \mathrm{~km}$ and $\sim 17.2 \mathrm{~km}$, respectively.

Figures 4(a)-(c) shows the MST radar winds ( $u, v$ and w) during the passage of cirrus cloud over Gadanki for the three Cases. In Case-(a), we observed a westerly wind (Figure 4(a)) with a maximum of $\sim 5 \mathrm{~m} / \mathrm{s}$ just below the cirrus cloud altitude from 01:00 LT to 04:30 LT. Zonal wind below the cloud height (BCH, $12.0-13.0 \mathrm{~km})$ is found to show similar variation as that of LDR within in the cloud (Figure 5(a)). Above the cloud height we have noticed weakening of westerly wind when the LDR is strong. Later again westerly wind BCH is found to show significant increase in magnitude with time. Even though it is difficult to depict variation of winds during this type of small-scale/short-time phenomena of cirrus cloud passage using Re-analysis data sets, a significant increase in the zonal wind with time (as in Figure 4(a)) can be explained by the existence of a sub-tropical westerly jet (as shown in Figure 6(a)) whose outer core existed to the North of Gadanki (13.45 N). No significant feature is observed in the meridional wind relating to the passage of cirrus, but it is becoming weaker in magnitude with time. Even though there is no significant feature noticed in vertical wind during the passage of cirrus during Case-(a), but it is found to be increasing in magnitude similar to that of zonal wind.

In Cases-(b) and -(c), we have noticed tropical easterly jet (Figure 4(b) and Figure 4(c)) which is often noticed in the months of (monsoon) June, July and August whose speed is found to be more than $30 \mathrm{~m} \cdot \mathrm{s}^{-1}$ in the present observation. As this jet is continuous for the months of time, so it is difficult to interpret the effect of this wind on the microphysical properties of cirrus clouds present in these heights. But, there may be a chance of these clouds to move in the direction of wind. In Case- $(b)$, the meridional wind is found to be slightly fluctuating from northerly to southerly above the cloud height (ABH, 16.5 - $17.5 \mathrm{~km}$ ) (Figure 4(b)). Within the cloud height (WCH, 13.5 - $15.5 \mathrm{~km}$ ) it shows similar trend as that of LDR but the meridional wind (southerly) is increasing in magnitude with decrease in LDR (Figure 4(b)). The vertical wind is also found to show strong fluctuations within the cloud height and above the cloud the vertical wind is found to be mostly upward (Figure 4(b)). In Case-(c), for the lower cloud layer, the meridional wind within the cloud height (WCH, 12.5 - $14.5 \mathrm{~km}$ ) is found to show almost opposite variation as that LDR (Figure 5(c)), i.e., meridional wind is decreasing with increase in LDR. Above the lower cloud layer (14.5 - $15.5 \mathrm{~km})$ northerly wind is dominant with an amplitude of $\sim 15 \mathrm{~m} / \mathrm{s}$ except between $\sim 3.5-4.5 \mathrm{~h}$ (Figure 4(c)). For the upper cloud layer, again the meridional wind is
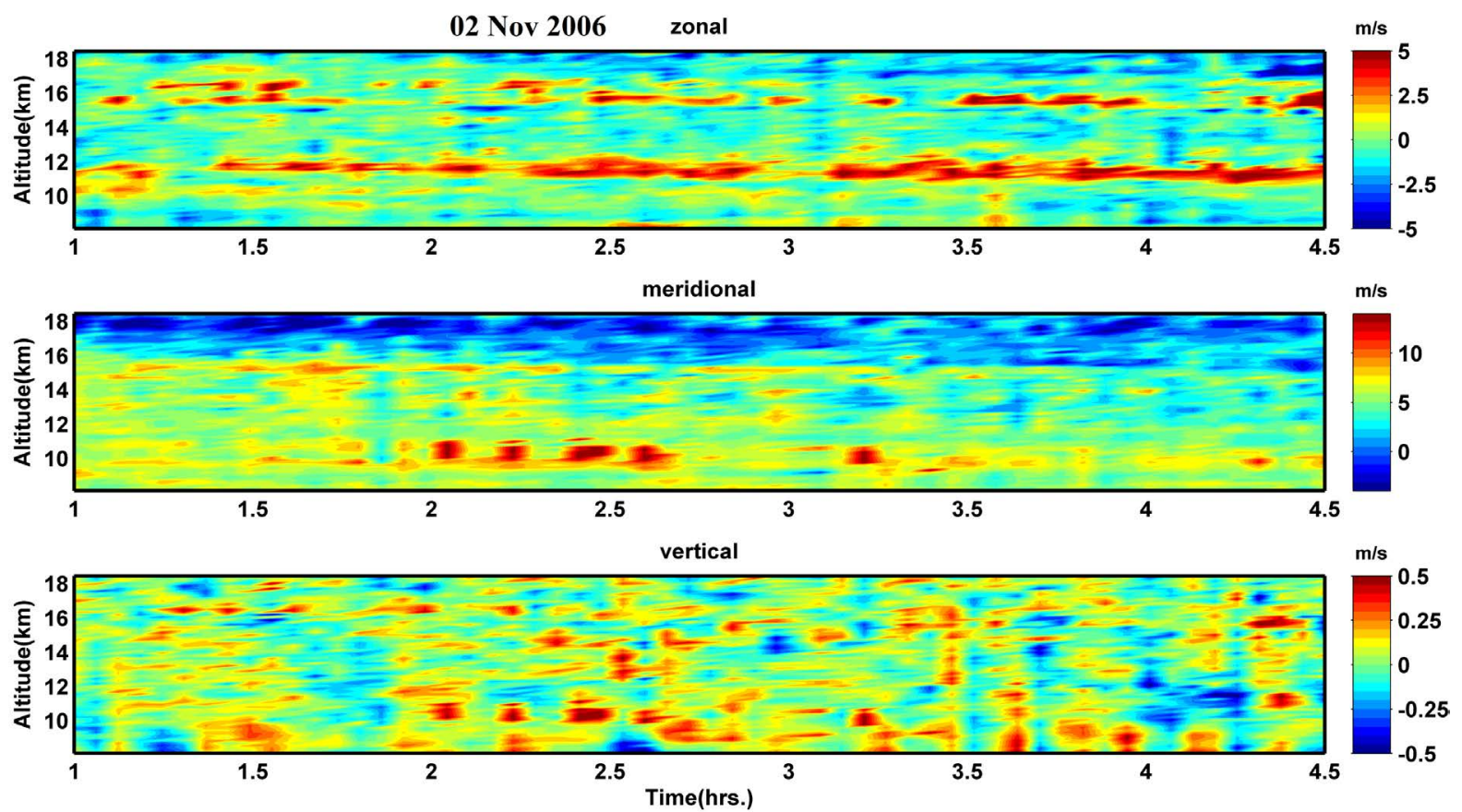

(a) 


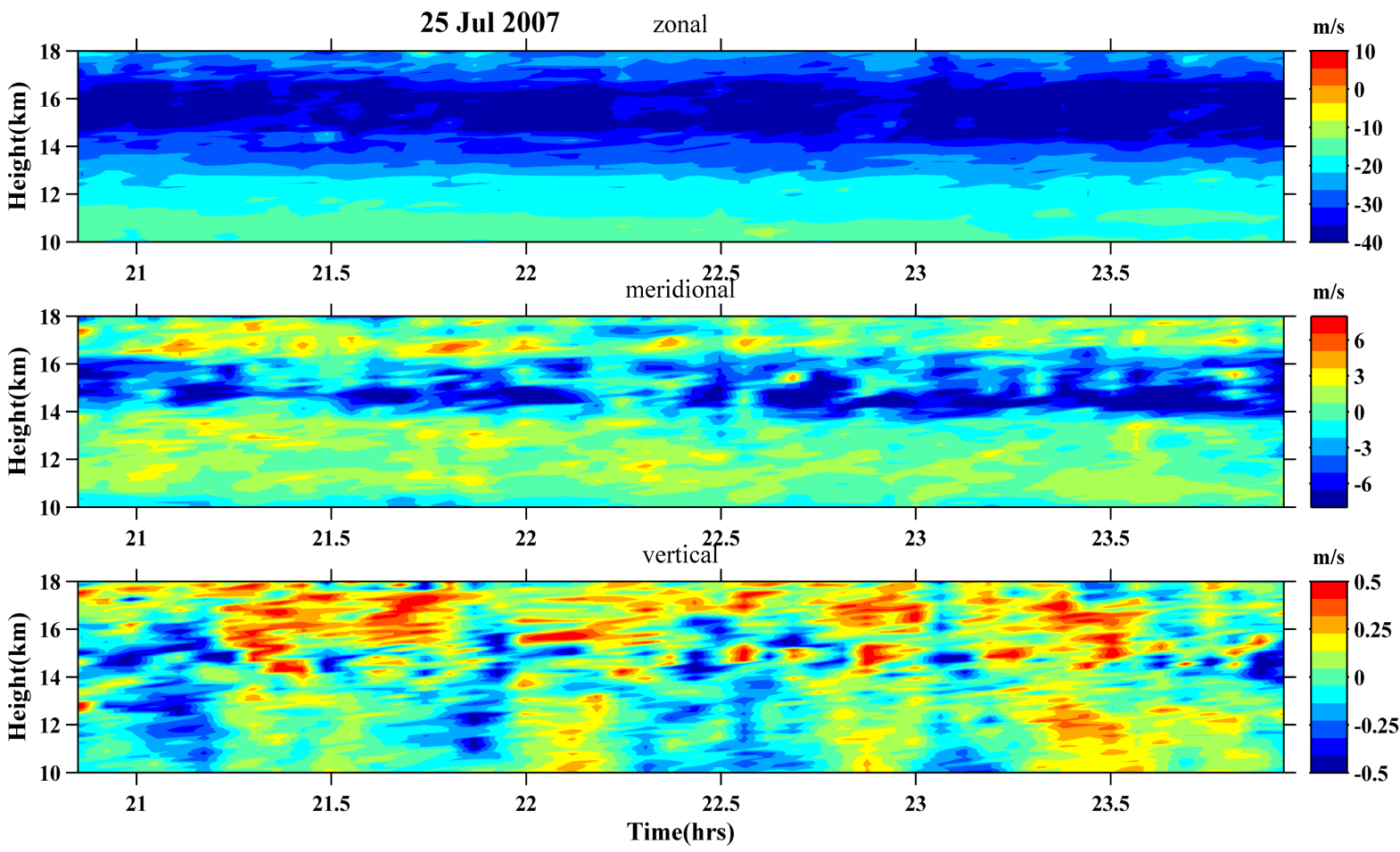

(b)

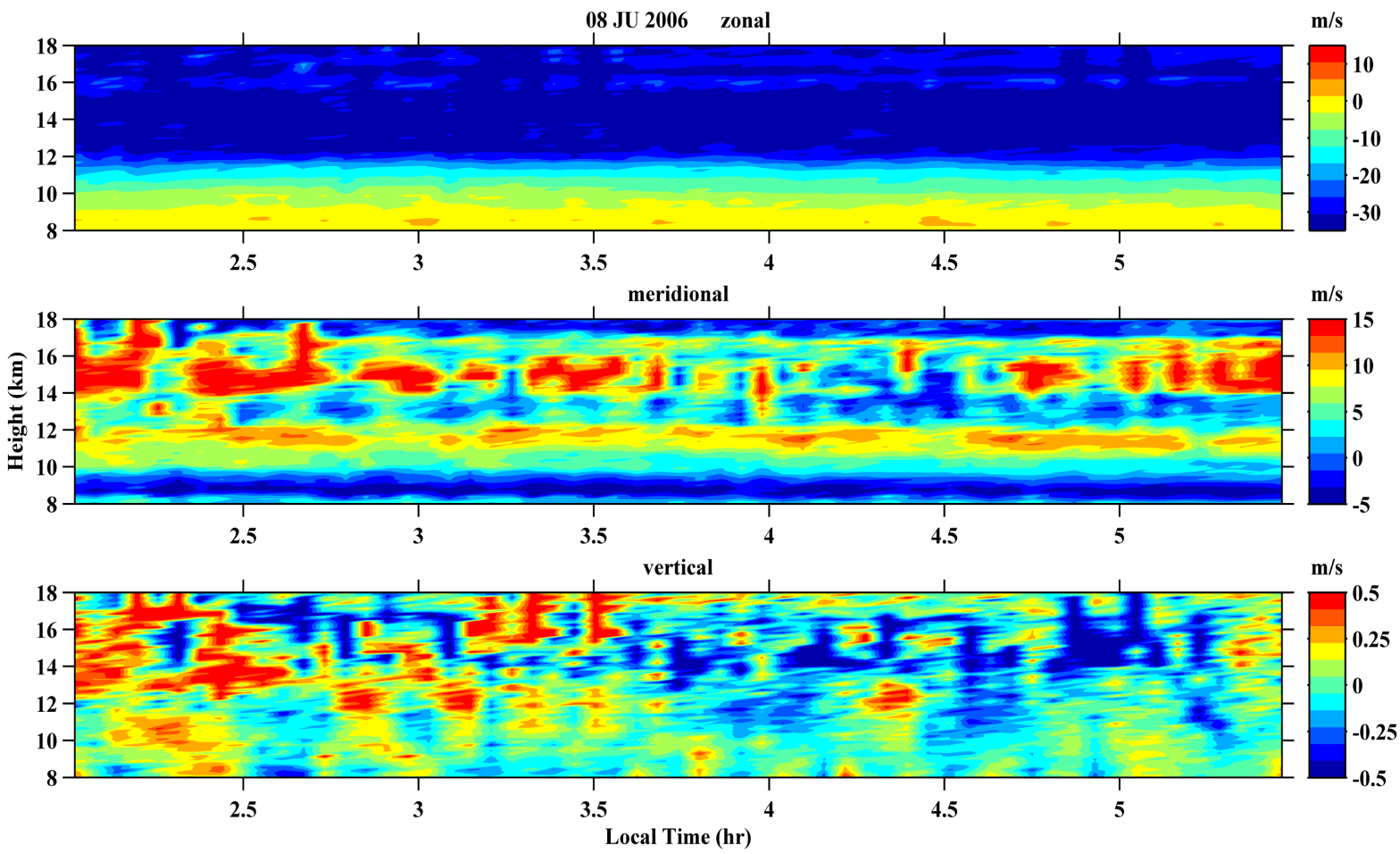

(c)

Figure 4. (a) Time-altitude plot of zonal (top panel), meridional (middle panel) and vertical (bottom panel) winds from 01:00 - 04:30 LT 02 November 2006; (b) Same as Figure 3(a) for 25 July 2007 between 20:50 - 24:00 LT; (c) Same as Figure 3(a) and Figure 3(b) for 08 June 2006 between 02:00 - 05:30 LT. 
found to show opposite variation as that of LDR (Figure 5(d)) as in Figure 5(c). Even though the vertical wind is slightly fluctuating, it is upward dominant up to $\sim 3: 15 \mathrm{~h}$; it is dominantly downward in the later hours.

In order to describe the synoptic scale features during the passage of cirrus clouds over the experimental site we have plotted Era-Interim zonal wind and potential temperature distributions over the latitudes from $5^{\circ}$ to $30^{\circ} \mathrm{N}$ for the three Cases. Figure 6(a) shows, latitude-altitude plot of zonal wind and potential temperature (black contour lines) over the Gadanki longitude (79.18E) at 2330 LT (top panel) 01 November 2006 and 0530 LT (bottom panel) 02 November 2006 for the Case-(a). It shows a sub tropical westerly jet around 10 to $12 \mathrm{~km}$.
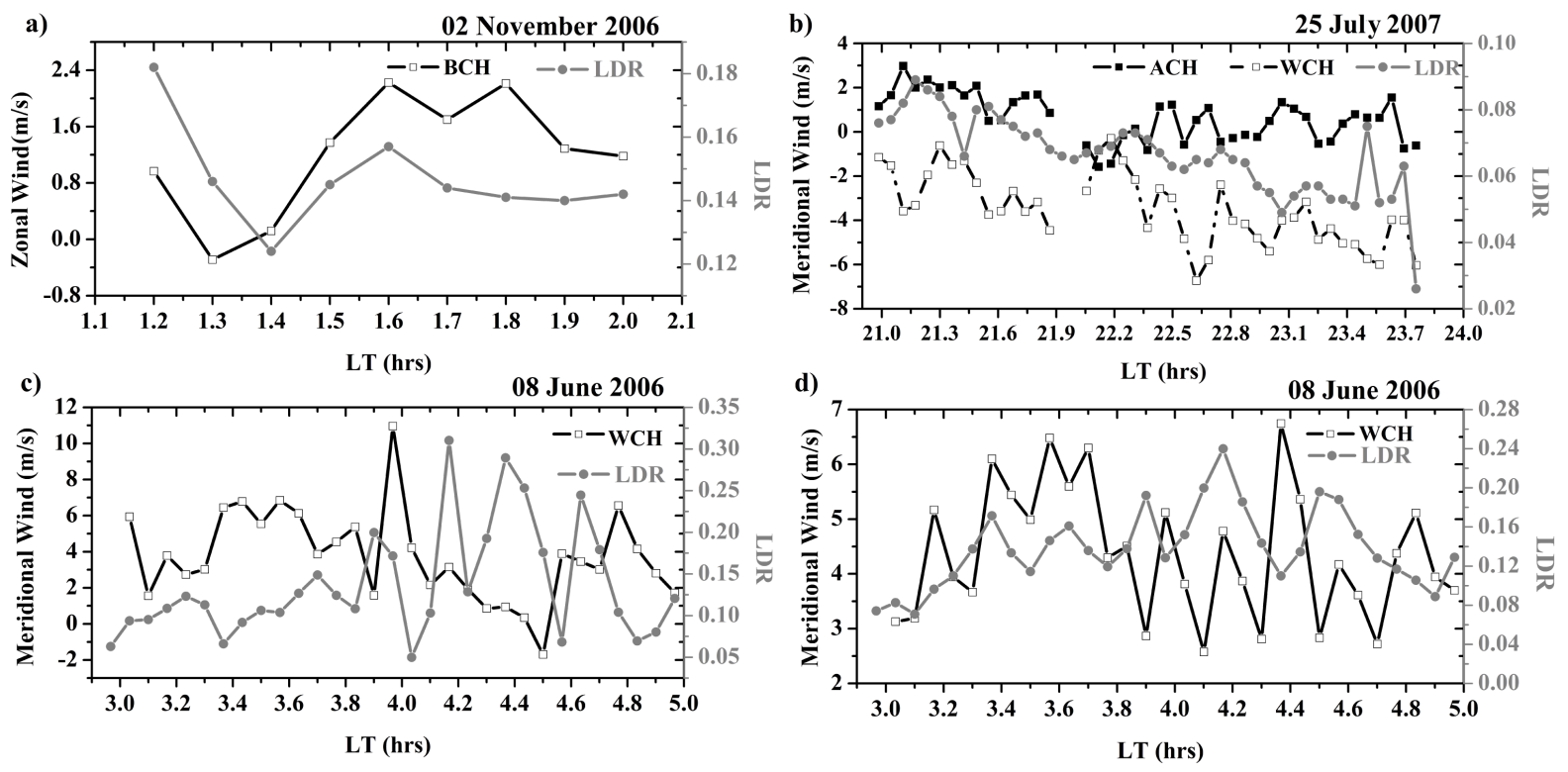

Figure 5. Time variation of mean (a) zonal wind below the cloud height (BCH) on 02 November 2006, (b) Meridional wind above and within the cloud height (ACH and WCH) on 25 July 2007 and (c) and (d) Meridional wind within the cloud height (WCH) for dual cloud noticed on 08 June 2006 with peak linear depolarization ratio (LDR).
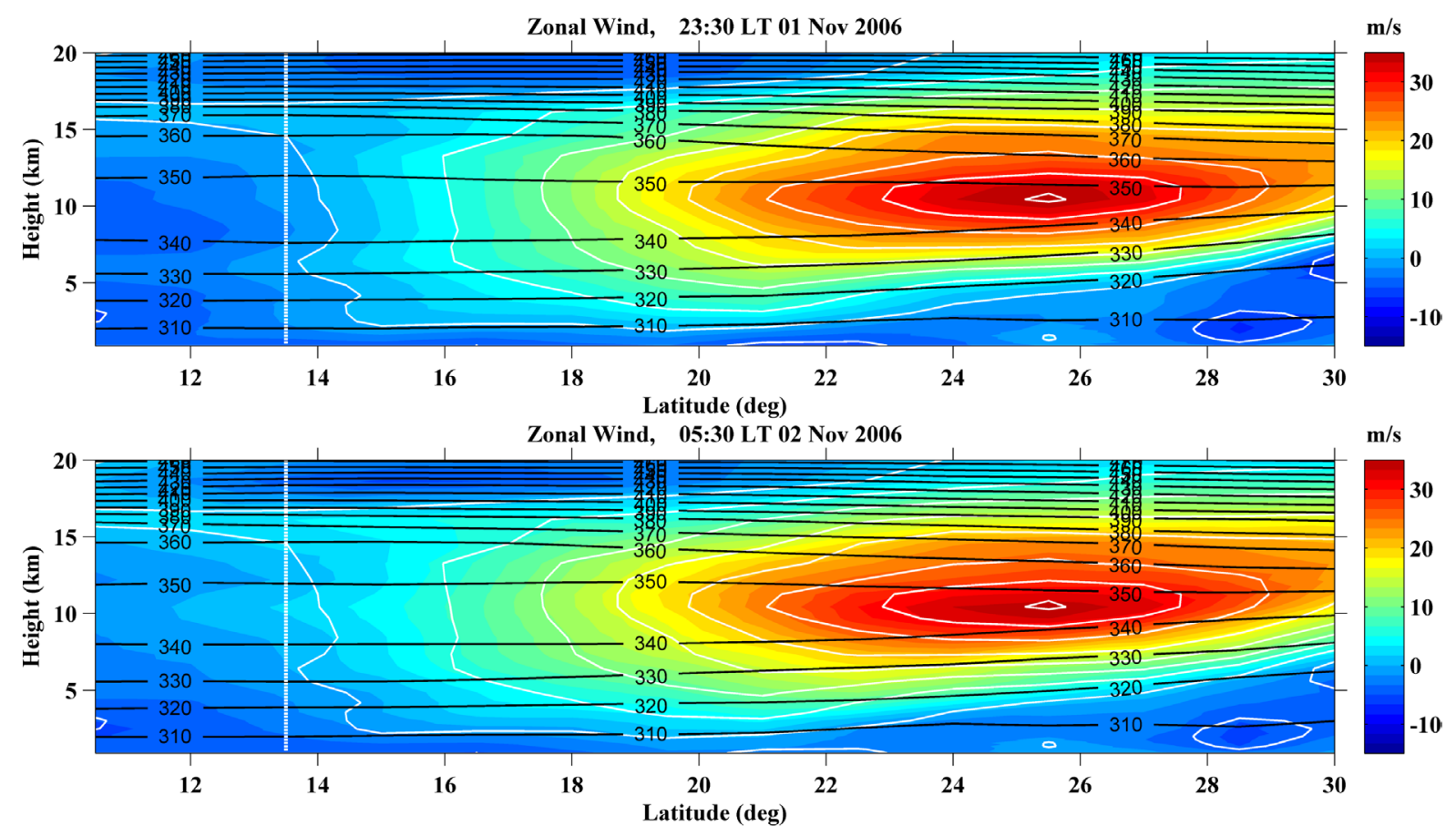

(a) 

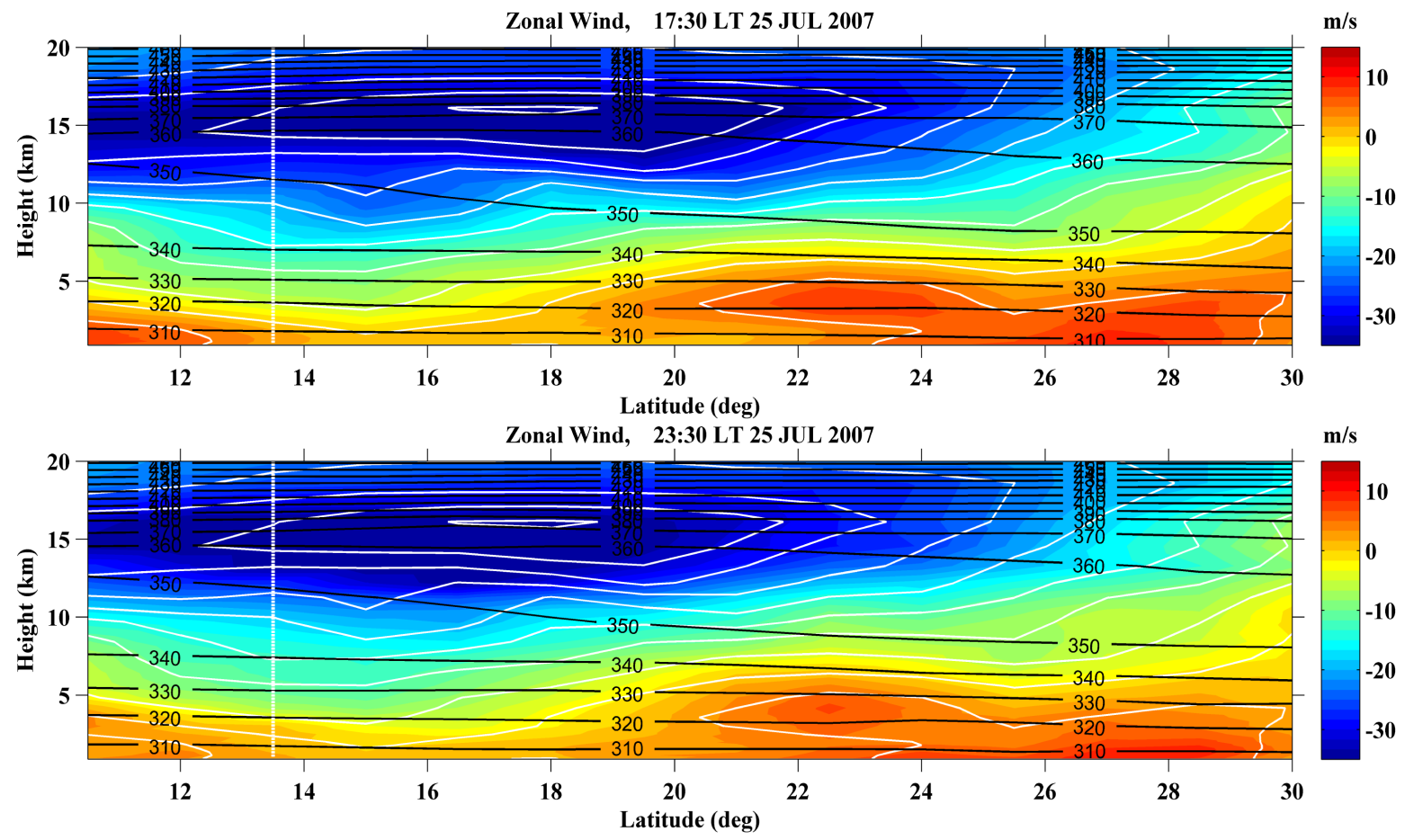

(b)

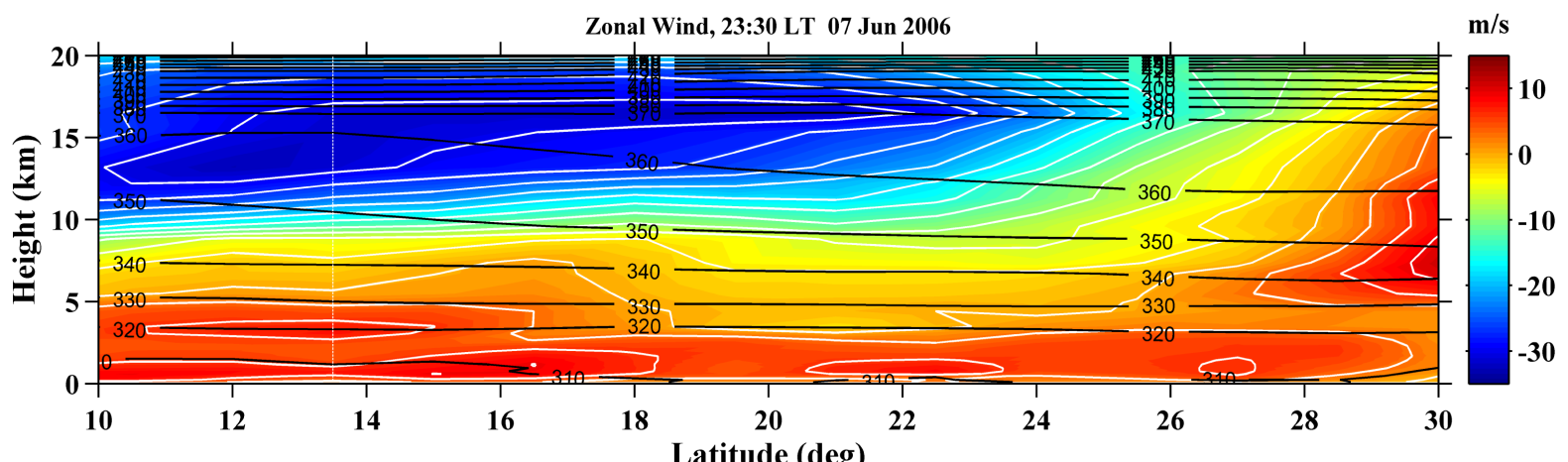

Latitude (deg)

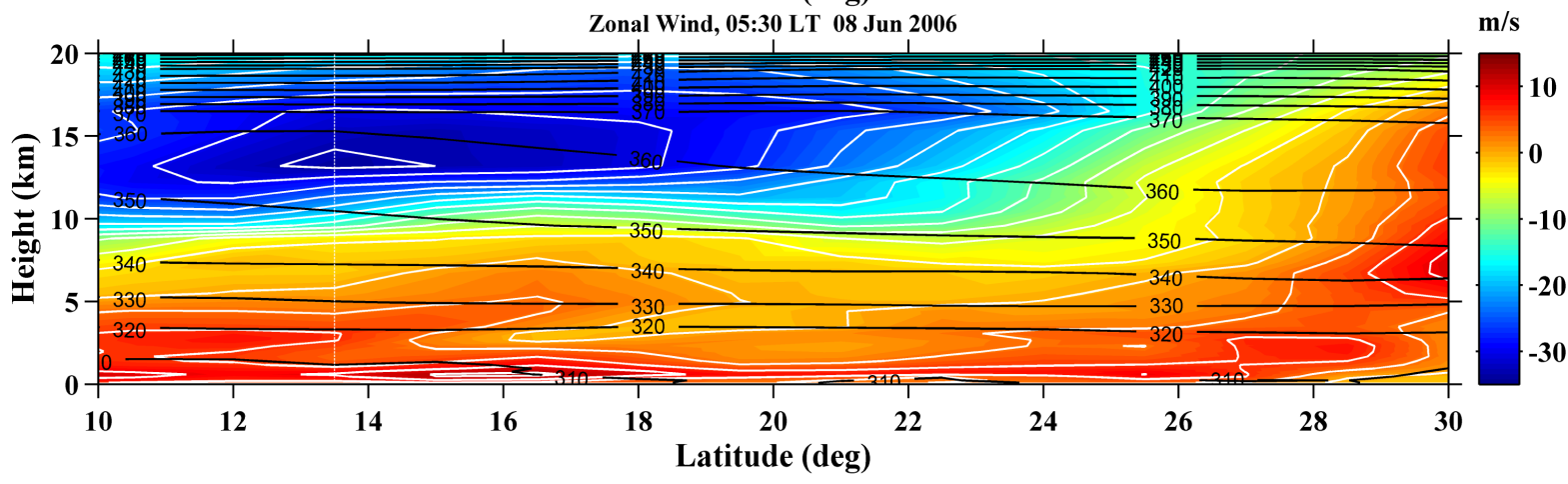

(c)

Figure 6. (a) Latitude-height plots of zonal wind (white contour with colored) and $\Theta$ (potential temperature) (black contour) along $79.5^{\circ} \mathrm{E}$ (top panel) at 23:30 LT 01 November 2006 and (bottom panel) at 05:30 LT 02 November 2006; (b) Same as Figure 5(a), (top panel) at 17:30 LT and (bottom panel) at 23:30 LT 25 July 2007; (c) Same as Figure 5(a) and Figure 5(b), (top panel) at 23:30 LT 07 June 2006 and (bottom panel) at 05:30 LT 08 June 2006. 
The westerly wind is found to be maximum (larger than $\left.40 \mathrm{~m} \cdot \mathrm{s}^{-1}\right)$ around $24^{\circ}-26^{\circ} \mathrm{N}$ latitude. Gadanki $\left(13.5^{\circ} \mathrm{N}\right)$ is southward of the core of the subtropical westerly jet. The westerly wind over Gadanki region showed a little increase in velocity (above $\sim 10 \mathrm{~km}$ ) with altitude and is $\sim 5 \mathrm{~m} \cdot \mathrm{s}^{-1}$ near tropopause region $(\sim 15.5 \mathrm{~km})$. The wind is found to show increase in speed with time as seen both from MST radar (Figure 4(a)) as well as from ERAInterim data (Figure 6(a)). Same as Figure 6(a), Figure 6(b) shows the latitude-altitude plot of the zonal wind (colored contour) and potential temperature (black lines) over the Gadanki longitude (79.18E) at $1730 \mathrm{LT}$ (top panel) and 2330 LT (bottom panel) 25 July 2007 for the Case-(b). It shows that, the tropical easterly jet whose core is existed at $16^{\circ}$ to $19^{\circ} \mathrm{N}$, which is very nearer to the observational site Gadanki $\left(13.45^{\circ} \mathrm{N}\right)$ with a maximum wind of $\sim 35 \mathrm{~m} \cdot \mathrm{s}^{-1}$ and is in agreement with the radar observed wind. Similar to Figure 5(b) we have plotted Figure 5(c) at 2330 LT and 0530 LT 07 and 08 June 2006 for the Case-(c), in which TEJ core existed between 11 - 14N, i.e. exactly over Gadanki region with a maximum wind speed of $\sim 35 \mathrm{~m} \cdot \mathrm{s}^{-1}$.

Also, double tropopause structure (Figure 7, left panel) with cold point tropopauses at $17.55 \mathrm{~km}(87.96 \mathrm{hPa})$ and $18.5 \mathrm{~km}(74.85 \mathrm{hPa})$ for the Case- $(a), 16.2 \mathrm{~km} \mathrm{(112.11} \mathrm{hPa)}$ and $16.8 \mathrm{~km} \mathrm{(100.90} \mathrm{hPa)} \mathrm{for} \mathrm{Case-(b),} \mathrm{and}$ $16.95 \mathrm{~km}(96.08 \mathrm{hPa})$ and $17.55 \mathrm{~km}(86.36 \mathrm{hPa})$ for Case- $(c)$ are identified, indicating that there is mass transport between troposphere and stratosphere, leading to tropopause folding (double tropopause). An interesting feature noticed from the potential temperature profiles (Figure 7, right panel) for the three Cases is that the potential temperature gradient within the cloud heights is found to be maximum, i.e. $\sim 13.5 \mathrm{~K} / \mathrm{km}$ for the Case- $(c)$ between 16 - $17.5 \mathrm{~km}$, is $\sim 3.6 \mathrm{~K} / \mathrm{km}$ for the Case-(b) between $14.5-16.5 \mathrm{~km}$, is $\sim 2.8 \mathrm{~K} / \mathrm{km}$ for the Case-(a) between $13-14.9 \mathrm{~km}$, and is $\sim 2.13 \mathrm{~K} / \mathrm{km}$ for the Case-(c) between $12-14.2 \mathrm{~km}$. The significance of maximum or

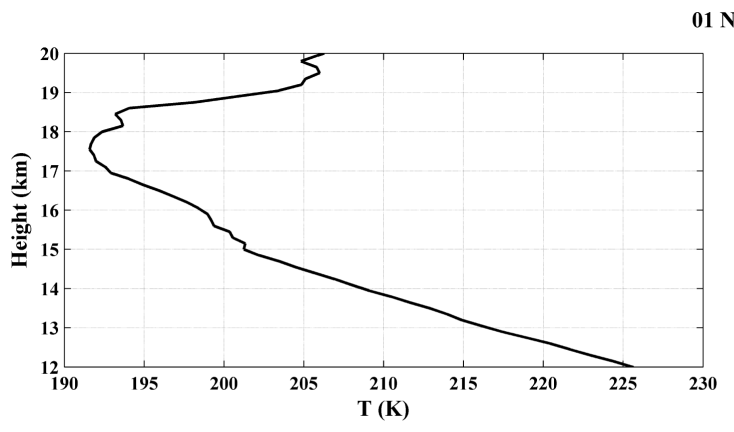

01 November 2006

25 July 2007
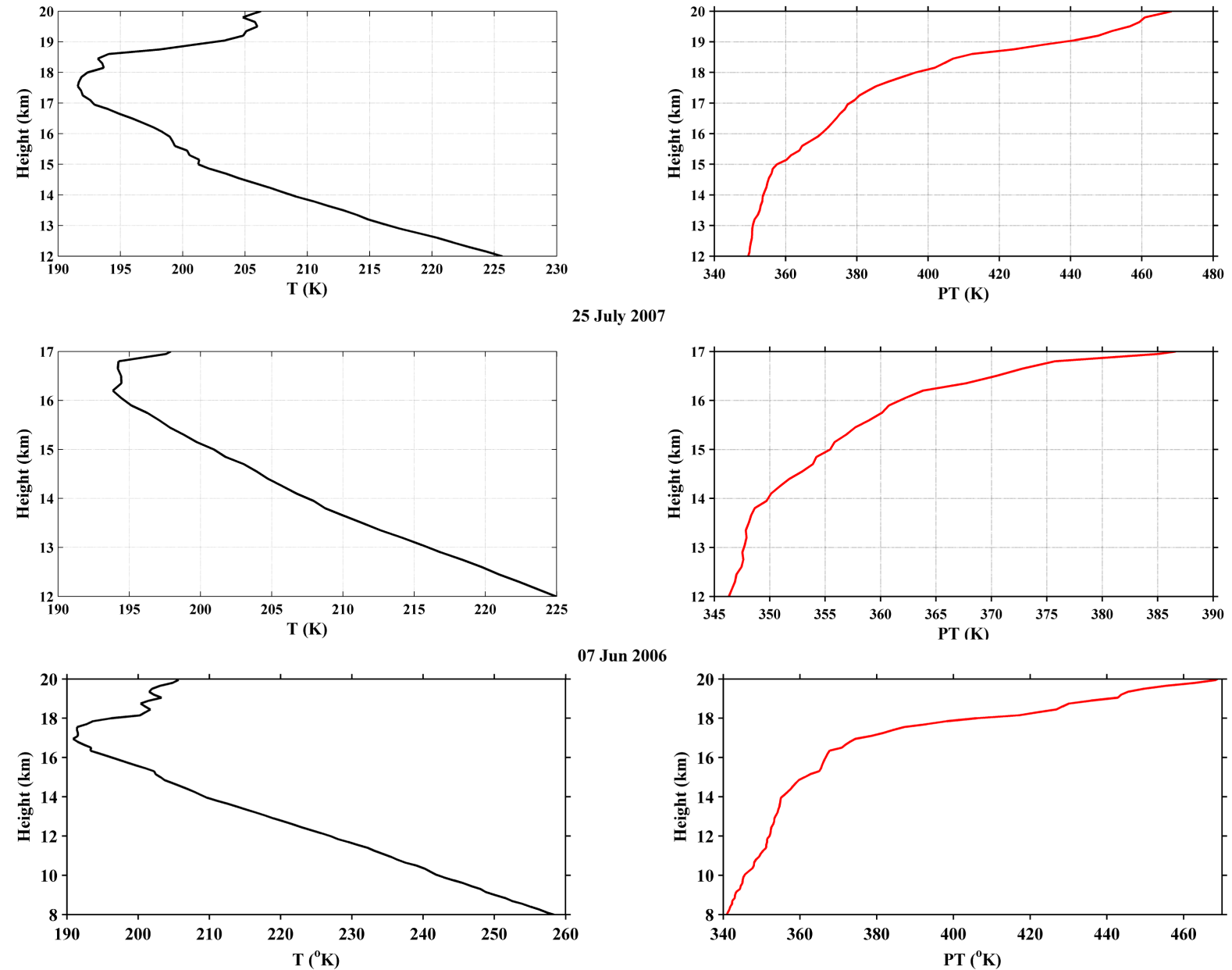

Figure 7. Altitude profiles of temperature and $\Theta$ (potential temperature (PT)) observed by radiosondes launched at 17:30 LT on (top panel) 01 November 2006, (middle panel) 25 July 2007 and (bottom panel) 07 June 2006. 
Minimum value of potential temperature gradient is to depict the region of maximum or minimum air mass mixing that takes place in the atmosphere. From the above values of potential temperature gradient one can state that the maximum air mass mixing will takes place when the cirrus cloud exists in the region of tropopause folding.

Though the coarser vertical and time resolutions of Era-Interim reanalysis (Figure 6(a) and Figure 6(b)), there is discrepancy from observations, it hasn't shown similar tropopause variation as the observed one. From 2330 LT 01 November 2006 and 0530 LT 02 November 2006, the estward-moving trough extended the subtropical tropopause region northward and produced a higher tropopause pressure at $13.5^{\circ} \mathrm{N}, 79.2^{\circ} \mathrm{E}$. At 17:30 LT and 23:30 LT 25 July 2007 tropopause pressure at $13.5^{\circ} \mathrm{N}, 79.2^{\circ} \mathrm{E}$ is similar to Case-(a) as the tropical tropopause region extended southward. On 07 June 2006 the tropical tropopause region has extended its core more towards south as seen from the Figure 6(c).

\section{Summary and Conclusions}

Using Mie lidar observations of cirrus clouds over Gadanki, we have determined the cloud vertical structure (i.e. the cloud base and top altitudes) for three different Cases one during winter and other two during summer monsoon season by using a quantitative approach based on the clear air assumption as proposed by [6]. Further, we have examined the variation (ascent/descent) of cloud base and top altitudes with the help of cloud backscatter coefficient $\beta_{\mathrm{c}}$, for all the three Cases and found that there is a significant descent during Case-(b) between 23:00 - 24:00 LT. From values of peak linear depolarization ratio $(0.182,0.089$ and 0.23$)$ it is found that the cirrus cloud is associated with randomly oriented, highly non-spherical ice particles in all the three cases as in Thomas et al. (1990). It is clear from the values of COD for the cirrus observed at different altitudes in Cases- $(a)$, - $(b)$ and $-(c)$ that the cirrus clouds are found to be visible in all cases except for the cirrus noticed near the tropoapuse region during Case-(c), which is sub-visual [6].

We have examined the effect of background winds on cirrus clouds with the help of MST radar collocated near to the lidar over Gadanki. A significant result noticed with the help of MST radar in present study is that zonal wind below the cloud height has shown similar variation as that of LDR during Case-(a) and above the cloud height zonal wind is weak when LDR is strong, later the zonal wind BCH has started increasing. The increase in zonal wind over Gadanki is further justified by the existence of outlier of sub-tropical westerly jet core from ECMWF Reanalysis dataset. By observing zonal wind for Case-(b) and Case- $(c)$ that, it is difficult to interpret the effect of TEJ on the microphysical properties of cirrus clouds present in these heights. Further justification has to be made by a number of simultaneous lidar and radar measurements during the passage of cirrus clouds in the monsoon period. But, within the cloud heights the meridional wind is found to show almost opposite variation as that of LDR, for Cases- $(b)$ and - $(c)$ i.e. the LDR is increasing when the meridional wind is decreasing in magnitude, vice versa.

The vertical wind is found to be increasing similar to that of zonal wind in magnitude during Case- $(a)$. In Case-(b) the vertical wind has shown strong fluctuations within the cloud height and it is found to be mostly upward above the cloud altitude and during Case-(c) it is found to be upward dominant up to $\sim 3: 15 \mathrm{~h}$ and is mostly downward in the later hours. [23] using MST radar has shown that there were enhanced horizontal winds, significant wind shear and significant decrease in vertical velocity at boundaries of cirrus. It indicates that strong circulation at the cloud boundaries will lead to entrainment in the vicinity of cirrus clouds.

Finally, an interesting feature from the Radiosonde data is the noticed double tropopause structures in all the three Cases of observation. The gradient of potential temperature is found to be maximum for Case- $(b)$ and - $(c)$ [10] when the cirrus cloud is present near the tropopause and is minimum when the cirrus cloud is well below the tropopause folding. The significance of maximum or minimum value of potential temperature gradient is to depict the region of maximum or minimum air mass mixing that takes place in the atmosphere.

\section{Acknowledgements}

Our sincere thanks to Director National Atmospheric Research Laboratory (NARL), Gadanki and also thankful to ECMWF for providing necessary datasets to carryout present research work.

\section{References}

[1] Parameswaran, K., Sunilkumar, S.V., Krishna Murthy, B.V., Satheesan, K., Bhavanikumar, Y., Krishnaiah, M. and 
Nair, P.R. (2003) Lidar Observations of Cirrus Cloud Near the Tropical Tropopause: Temporal Variations and Association with Tropospheric Turbulence. Atmospheric Research, 69, 29-49.

http://dx.doi.org/10.1016/j.atmosres.2003.08.002

[2] Zerefos, C.S., Eleftheratos, K., Balis, D.S., Zanis, P., Tselioudis, G. and Meleti, C. (2003) Evidence of Impact of Aviation on Cirrus Cloud Formation. Atmospheric Chemistry and Physics, 3, 1633-1644. http://dx.doi.org/10.5194/acp-3-1633-2003

[3] Lynch, D.K., Sassen, K., Starr, D.O’C. and Stephens, G. (2002) Cirrus. Oxford University Press, New York, 18.

[4] Ramaswamy, V. and Ramanathan, V. (1989) Solar Absorption by Cirrus Clouds and Maintenance of the Tropical Upper Troposphere Thermal Structure. Journal of the Atmospheric Sciences, 46, 2293-2310. http://dx.doi.org/10.1175/1520-0469(1989)046<2293:SABCCA>2.0.CO;2

[5] Devara, P.C.S., Raj, P.E., Sharma, S. and Pandithurai, G. (1995) Real-Time Monitoring of Atmospheric Aerosols Using a Computer Controlled Lidar. Atmospheric Environment, 29, 2205-2215. http://dx.doi.org/10.1016/1352-2310(94)00355-O

[6] Sassen, K. and Cho, B.S. (1992) Subvisual-Thin Cirrus Lidar Dataset for Satellite Verification and Climatological Research. Journal of Applied Meteorology, 31, 1275-1285.

http://dx.doi.org/10.1175/1520-0450(1992)031<1275:STCLDF>2.0.CO;2

[7] Ansmann, A., Wandinger, U., Riebesell, M., Weitkamp, C. and Michaelis, W. (1992) Independent Measurement of Extinction and Backscatter Profiles in Cirrus Clouds by Using a Combined Raman Elastic Backscatter Lidar. Applied Optics, 31, 7113-7131. http://dx.doi.org/10.1364/AO.31.007113

[8] Heymsfield, A.J. and McFarquahar, G.M. (1996) High Albedoes of Cirrus in the Tropical Pacific Warm Pool: Microphysical Interpretation CEPEX and from Kwajalein, Marshall Islands. Journal of the Atmospheric Sciences, 53, 2424-2541. http://dx.doi.org/10.1175/1520-0469(1996)053<2424:HAOCIT>2.0.CO;2

[9] Goldfarb, L., Keckhut, P., Chanin, M.L. and Hauchecorne, A. (2001) Cirrus Climatological Results from Lidar Measurements at OHP. Geophysical Research Letters, 28, 1687-1690. http://dx.doi.org/10.1029/2000GL012701

[10] Yamamoto, M.K., et al. (2009) Wind Observation around the Tops of the Midlatitude Cirrus by the MU Radar and Raman/Mie Lidar. Earth Planets Space, 61, e33-e36.

[11] Jensen, E.J., Toon, O.B., Selkirk, H.B., Spinhirne, J.D. and Schoeberl, M.R. (1996) On the Formation and Persistence of Subvisible Cirrus Clouds near the Tropical Tropopause. Journal of Geophysical Research, 101, 21361-21375.

[12] Sivakumar, V., Bhavanikumar, Y., Rao, P.B., Mizutani, K., Aoki, T., Yasui, M. and Itabe, T. (2003) Lidar Observed Characteristics of the Tropical Cirrus Clouds. Radio Science, 38, Published Online. http://dx.doi.org/10.1029/2002RS002719

[13] Dowling, D.R. and Radke, L.F. (1990) A Summary of the Physical Properties of Cirrus Clouds. Journal of Applied Meteorology, 29, 970-978. http://dx.doi.org/10.1175/1520-0450(1990)029<0970:ASOTPP >2.0.CO;2

[14] Prabhakara, C., Fraser, R.S., Dalu, G., Wu, M., Curran, R.J. and Styles, T. (1988) Thin Cirrus Clouds: Seasonal Distribution over Oceans Deduced from Nimbus-4 IRIS. Journal of Applied Meteorology, 27, 379-399. http://dx.doi.org/10.1175/1520-0450(1988)027<0379:TCCSDO>2.0.CO;2

[15] Winker, D.M. and Trepte, C.R. (1998) Laminar Cirrus Observed near the Tropical Tropopause by LITE. Geophysical Research Letters, 25, 3351-3354. http://dx.doi.org/10.1029/98GL01292

[16] Boehm, M.T., Verlinde, J. and Ackerman, T.P. (1999) On the Maintenance of High Tropical Cirrus. Journal of Geophysical Research: Atmospheres, 104, 24423-24433. http://dx.doi.org/10.1029/1999JD900798

[17] Immler, F. and Schrems, O. (2002) Determination of Tropical Cirrus Properties by Simultaneous Lidar and Radiosonde Measurements. Geophysical Research Letters, 29, 2090.

[18] Beyerle, J., Schäfer, H.J., Neuber, R., Schrems, O. and Macdemid, I.S. (1998) Dual Wavelength Lidar Observation of Tropical High-Altitude Cirrus Clouds during the ALBATROSS 1996 Campaign. Geophysical Research Letters, 25, 919-922. http://dx.doi.org/10.1029/98GL00491

[19] Houze Jr., R.A. (1993) Cloud Dynamics. International Geophysics Series, 53, Academic Press, Waltham.

[20] Webster, P.J. and Stephens, G.L. (1984) Tropical Upper-Tropospheric Extended Clouds: Inferences from Winter MONEX. Journal of Atmospheric Science, 37, 1521-1541. http://dx.doi.org/10.1175/1520-0469-37.7.1521

[21] Reichardt, J. (1999) Optical and Geometrical Properties of Northern Midlatitude Cirrus Clouds Observed with a UV Raman Lidar. Physics and Chemistry of the Earth, Part B: Hydrology, Oceans and Atmosphere, 24, 255-260. http://dx.doi.org/10.1016/S1464-1909(98)00047-1

[22] Starr, D. and Cox, S.K. (1985) Cirrus Clouds. Part II: Numerical Experiments on the Formation and Maintenance of Cirrus. Journal of the Atmospheric Sciences, 42, 2682-2694. http://dx.doi.org/10.1175/1520-0469(1985)042<2682:CCPINE>2.0.CO;2 
[23] Kumar, Y.B., Kumar, V.S., Jain, A.R. and Rao, P.B. (2001) MST Radar and Polarization Lidar Observations of Tropical Cirrus. Annales Geophysicae, 19, 873-883. http://dx.doi.org/10.5194/angeo-19-873-2001

[24] Fortuin, J.P.F., Becker, C.R., Fujiwara, M., Immler, F., Kelder, H.M., Scheele, M.P., Schrems, O. and Verver, G.H.L. (2007) Origin and Transport of Tropical Cirrus Clouds Observed over Paramaribo, Suriname (5.8 $\left.{ }^{\circ} \mathrm{N}, 55.2^{\circ} \mathrm{W}\right)$. Journal of Geophysical Research: Atmospheres, 112, Published Online. http://dx.doi.org/10.1029/2005JD006420

[25] Rao, P.B., Jain, A.R., Kishore, P., Balamuralidhar, P., Damle, S.H. and Viswanathan, G. (1995) Indian MST Radar Part-I: System Description and Sample Wind Vector Measurements in ST Mode. Radio Science, 30, 1125-1138. http://dx.doi.org/10.1029/95RS00787

[26] Kumar, Y.B., Raghunath, K., Kumar, V.S., Rao, P.B., Jain, A.R., Mizutani, K., Aoki, T., Yasui, M. and Itabe, T. (1999) NMRFCRL Lidar System Description and Data Processing. Proceedings of IRSI '99, Bangalore, 560-570.

[27] Fernald, F.G. (1984) Analysis of Atmospheric Lidar Observations: Some Comments. Applied Optics, 23, 652-653. http://dx.doi.org/10.1364/AO.23.000652

[28] Platt, C.M.R., Young, S.A., Carswell, A.I., Pal, S.R., McCormick, M.P., Winker, D.M., et al. (1994) The Experimental Cloud Lidar Pilot Study (ECLIPS) for Cloud-Radiation Research. Bulletin of the American Meteorological Society, 75, 1635-1645. http://dx.doi.org/10.1175/1520-0477(1994)075<1635:TECLPS>2.0.CO;2

[29] Pal, S.R., Steinbrecht, W. and Carswell, A.I. (1992) Automated Method for Lidar Determination of Cloud Base Height and Vertical Extent. Applied Optics, 31, 1488-1494. http://dx.doi.org/10.1364/AO.31.001488

[30] Simmons, A., Uppala, S., Dee, D. and Kobayashi, S. (2007) ERA-Interim: New ECMWF Reanalysis Products from 1989 onwards. ECMWF Newsletter, 110, 29-35.

[31] Thomas, L., Cartwright, J.C. and Wareing, D.P. (1990) Lidar Observations of the Horizontal Orientations of Ice Crystals in Cirrus Clouds. Tellus, 42, 211-216. http://dx.doi.org/10.1034/j.1600-0889.1990.00001.x-i1

[32] Platt, C.M.R., Young, S.A., Manson, P.J., Peterson, G.R., Marsden, S.C., Austin, T. and Churnside, J.H. (1998) The Optical Properties of Equatorial Cirrus from Observations in the ARM Pilot Radiation Observation Experiment. Journal of the Atmospheric Sciences, 55, 1977-1996. http://dx.doi.org/10.1175/1520-0469(1998)055<1977:TOPOEC>2.0.CO;2

[33] Takahashi, T. and Kuhara, K. (1993) Precipitation Mechanism of Cumulonimbus Clouds at Pohnpei, Micronesia. Journal of the Meteorological Society of Japan, 71, 21-31.

[34] Chen, W.N., Chiang, C.W. and Nee, J.B. (2002) Lidar Ratio and Depolarization Ratio for Cirrus Clouds. Applied Optics, 41, 6470-6476. http://dx.doi.org/10.1364/AO.41.006470 
Scientific Research Publishing (SCIRP) is one of the largest Open Access journal publishers. It is currently publishing more than 200 open access, online, peer-reviewed journals covering a wide range of academic disciplines. SCIRP serves the worldwide academic communities and contributes to the progress and application of science with its publication.

Other selected journals from SCIRP are listed as below. Submit your manuscript to us via either submit@scirp.org or Online Submission Portal.
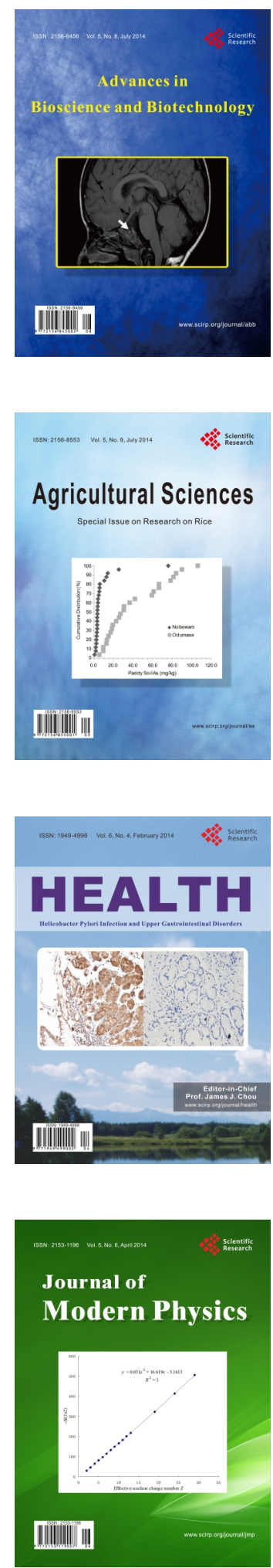
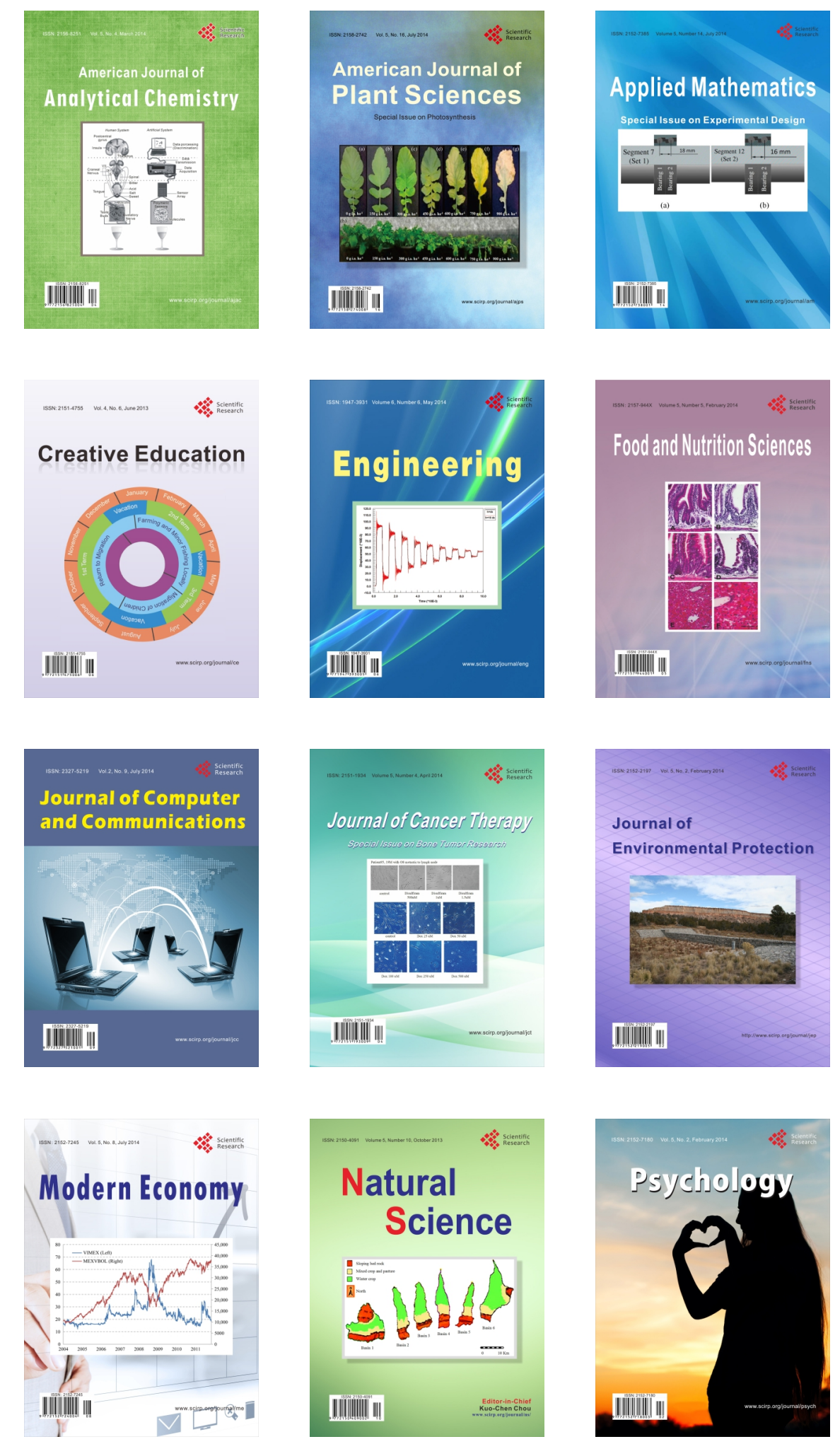